\title{
THE DEVELOPMENT OF CONTEXTUAL LEARNING BASED TEXTBOOK TO IMPROVE STUDENTS' CRITICAL AND CREATIVE THINKING ABILITY OF ISLAMIC EDUCTION SUBJECT AT MAN SURABAYA
}

\author{
Rahmat Arofah Hari Cahyadi \\ rahmatmailfile@yahoo.co.id
}

\begin{abstract}
This study aimed to identify: (1) the validity of the developed contextual learning based textbook (2) practicality of the developed contextual learning based textbook (3) effectiveness of the developed contextual learning based textbook to improve students' critical and creative thinking ability. This study used developement research design by adopting ADDIE model (Analysis, Design, Development, Implementation, and Evaluation). This study consisted of three stages: introduction, developement, and test of effetiveness. The validity result of textbook from 36 expert's assessment items showed that 22 items were very suitable and 14 items were suitable. The textbook practicality was seen from checklist points achievement for contextual learning based textbook. The result of gain score analysis of students 'critical thinking ability was 0.769 or categorized as high, meaning that the use of contextual learning based textbook was effective to improve students' critical thinking ability. The result of gain score analysis of students 'creative thinking ability was 0.775 or categorized as high, meaning that the use of contextual learning based textbook was effective to improve students' creative thinking ability.
\end{abstract}

Keywords: Textbook, Contextual learning, Critical Thinking, Creative Thinking.

\section{A. Introduction}

Islamic education in schools is considered as the most important medium and potential to instill children's personality towards a better future. The people expect that Islamic Education is able to equip as well as become a moral fortress of the negative influence of modern life that is hedonistic-materialistic in the developing society that tends to be individual and permissive. ${ }^{1}$

Meanwhile, there are still some problems in Islamic Education lerning. According to Muhamin based on ideas of Kamarudin Hidayat, Islamic Education learning was still oriented to learn about Religion, so that many students

1 Farikhatin, Anis. Menyoal Peran Afektif Pendidikan Agama di Sekolah. Makalah ini dipresentasikan dalam Seminar dan Lokakarya Tahap Kedua "Pendidikan Pluralisme dan Multikulturalisme", di Merauke 9 s.d 12 Mei 2011. know the values of religious teachings but their behavior is not relevant to the knowledge. ${ }^{2}$

Jannah mentioned that problem in Islamic Education learning were the lack of students' learning independence, the absence of textbook suitable to students' characteristics and teachers' difficulty in developing textbooks as well as lack of time allocation. ${ }^{3}$ Efendy also mentioned that Islamic Education textbook was not adapted to students' characteristics and not suitable with the existing guidebook. ${ }^{4}$

${ }^{2}$ Muhaimin. (2005). Pengembangan Pendidikan Islam. Surabaya: Pusat Studi Agama Politik dan Masyarakat.

3 Jannah, Raudlatul. (2009). Pengembangan Paket Pembelajaran Pendidikan Agama Islam Kelas VIII dengan Model Dick, Carey dan Carey di SMP Negeri 2 Banyuwangi. (Tesis tidak dipublikasikan). Universitas Negeri Malang

4 Efendiy, Khoirul. (2012). Pengembangan Bahan Ajar Pendidikan Agama Islam SMP Kelas VIII dengan Model Dick, Carey \& Carey 
Islamic Education was bored subject for students because of dogma and indoctrination of religious norms that were considered very sacred to be studied so that there was no open space for students to be more critical and creative. The development of contextual learning based textbooks was needed to answer this issue. It is expected that the contents becomes more easily absorbed by students without leaving contextual learning itself. Thus, students are encouraged to improve critical and creative thinking ability so that knowledge students learn can be implemented in school and their daily life.

Through developing contextual learning based textbooks, the learning objectives based on the characteristics of contextual learning can be achieved. Students are expected to have critical and creative thinking ability in understanding the context more deeply to solve real-world problems critically so that it can be applied in their real-world situations.

Based on the problems, the research questions were formulated as follows: 1 . How is the validity of contextual learning based textbook to improve students' critical and creative thinking ability of islamic eduction subject at MAN surabaya ?, 2. How is the practicality of developed contextual learning based textbook to improve students' critical and creative thinking ability of islamic eduction subject at MAN Surabaya ?, 3. How is the effectiveness of developed contextual learning based textbook to improve students' critical and creative thinking ability of islamic eduction subject at MAN Surabaya?

This study was aimed: 1 . To describe the validity of contextual learning based textbook to improve students' critical and creative thinking ability of islamic eduction subject at MAN surabaya, 2. Describe the practicality of developed contextual learning based textbook to improve students' critical and creative thinking ability of islamic eduction subject at MAN surabaya, 3. To describe the effectiveness of contextual learning based textbook to improve students' critical and creative thinking ability of islamic eduction subject at MAN surabaya.

di SMPN 04 Ampelgading Malang. (Tesis tidak dipublikasikan). Universitas Negeri Malang.

\section{B. Method}

This study used developement research design by adopting ADDIE model (Analysis, Design, Development, Implementation, and Evaluation). This study consisted of three stages: 1) preliminary study, 2) textbook development, 3) textbook validation and 4) textbook testing.

The subjects of the study were tenth graders at Madrasah Aliyah Negeri Surabaya. Data were collected using test, observation, interviews and documentation and analyzed using descriptive, evaluative and experimental methods.

\section{Result and Discussion}

This discussion will describe the development of contextual learning based textbooks to improve students' critical and creative thinking ability of Islamic Education subject in MAN Surabaya. This study was begun From the preliminary research (preresearch), continued to development stage with the ADDIE (Analysis, Design, Development, Impelementation and Evaluation) model and ended to the effectiveness test contextual learning based textbooks to improve students' critical and creative thinking ability of Islamic Education subject in MAN Surabaya.

Analysis is the first stage in developing contextual learning based textbooks with the ADDIE model. Through a performance analysis, it was found that teaching methods and the unavaibality of textbook were the problem experienced by teachers in teaching Islamic Education subjects. Thus, the method used by teachers was still teacher-centered approach, dogmatic and not relevant between theory and real. It was because Islamic Education subject has not been designed to improve the ability to think critically and creatively in dealing religious and social issues to their environment.

The problem of Islamic Education learning were the lack of students' learning independence, the absence of textbook suitable to students' characteristics and teachers' difficulty in developing textbooks as well as lack of time allocation. Islamic Education textbook was not adapted to students' 
characteristics and not suitable with the existing guidebook. Meanwhile, Hartono states that Islamic Education requires special methods in learning so that it can provide meaningful experience for students learning. ${ }^{5}$

Performance problems experienced by Islamic education Subject teachers were the availability of textbooks developed using contextual approach to improve students' critical thinking and creative thinking ability. Thus, it was necessary for researcher to develop textbook that fulfilled the elements such; ease in using, using contextual approach, and being able to improve students' critical and creative thinking skills.

Through a student analysis, it was found that students did not actively involve in learning acitivity. The Islamic Education subject for students is so dogmatic and the material is so textual for students. The teaching materials used were textbooks and student workshet made by school and no textbooks were designed specifically for the needs of the students.

Through learning material analysis, the material was not suitable with core standards and conpetence standards. Morever, the depth of material prepared by the teacher did not meet the elements of facts, concepts, principles and procedures that seemed to be not systematically conceptualized. The material given is based on the order of the material in book. The content has not lead to efforts to stimulate students to increase their ability to think critically and creative thinking ability and not linked to students' real-life around their surroundings.

Through the learning material analysis, the materials in textbook were designed based on its suitability of facts, concepts, principles and procedures with core competencies and basic competencies that have been established, and based on contextual learning approach (subject matter can be linked to the student's daily life in the environment around the student.

The design of the developed contextual learning based textbook to improve students'

${ }^{5}$ Hartono. (2012). Pengembangan Bahan Ajar Pendidikan Agama Islam Berbasis Pembelajaran Tematik Pada Siswa Kelas III Madrasah Ibtidaiyah. (Tesis tidak dipublikasikan). UIN Maulana Malik Ibrahim. critical and creative thinking ability of Islamic Education subject was performed in various steps so that it was so comprehensive. In the development area, the concept of design has a third sense, namely; in addition to understanding the design of learning systems that are macro and micro learning design, but also be a special application. ${ }^{6}$

The several steps done by researchers on the textbook design section is; 1) Determining the competence of textbook material; 2) Determining the purpose of learning materials; 3) Designing the subject matter of the textbook based on facts, concepts, principles and learning procedures; 4) Making core learning material of textbook; 5) preparing the textbooks; 6) planning teaching and learing set; 7) Designing evaluation tools;

The activities of development stage included; producing textbooks, revision of textbook products, textbook validation and testing of textbooks on a limited scale.

Stages in textbook production were printing the textbookprinted based on beginning of research both in terms of design and cover, content, systematic, lan guage, table content, drawings, graphics and visual illustrations, including textbook sizes, paper and textbook thickness.

Textbooks used as learning resources to achieve learning objectives must be qualified.. The criteria used to determine the quality of textbooks, can be observed from several perspectives such as;appearance, clarity of concepts, relevance to the curriculum, interest, motivation, stimulate student activity. Interesting illustrations, communicative, supporting other subjects, respecting individual differences and prioritizing values.

To guarantee the quality of textbooks and conformity with the elements of writing, the textbook was consulted to three experts regarding the content of textbook material, systematic textbooks, grammar of the booktext,

${ }^{6}$ Seels, B. B \& Richey, R. C. (1994 : 40). Instructional Technology: The Definition and Domains Of The Fields. Washington D.C: AECT 
including the display of tables, figures, graphics as well as visual illustrations.

The textbook product revision was made based on references, inputs and suggestions from several sources; input from Islamic Education teachers, input from direct observation, islamic education book reference and Guidelines of Content Standard published by the Ministry of Religious Affairs, advice from supervisors that was proved by validation letter. The inputs and suggestions from experts were given in revision process and approved in the form of validation validation letters and then tested in accordance with the purpose of developing textbooks.

The revision started from the textbook cover design, the textbook systematic based on contextual learning approach, the content of the textbook based on content standard and the interpretation of the concept with the surrounding environment, the illustration of the drawing, the table, the graph and the visual appearance to attract and supports explanations in developed textbooks.

To obtain the validity of textbook, validity test was performed by expert to guarantee the properness of textbook usage. According to Borg and Gall (1989:624) educational research and develompment is process used to develop and validate educational product.

In the validity test, the textbook was developed from aspects of textbook content, systematics, language, tables, drawings, graphics and visual illustrations. Thus, the experts' notes were recommendation for writer to do revision of textbook.

After recommendation and test of validity, the experts gave the letter to state that textbook product made by the researcher was valid to be tested on a wide scale.

To know the effectiveness, it was necessary to test the developed textbooks. Richey and Klein (2007: 1), states that development as a process of translating design specifications into physical forms related to systematic learning design, developing and evaluating processes to establish empirical foundations for the creation of new learning and non-learning products or enhancement models of development which has existed. To produce a particular product, analytical research was conducted and it was also necessary to test the effectiveness of these products that can be used in the wider community.

A limited test was conducted in three times. A limited trial was conducted to test the quality of textbooks before being tested on a large-scale test. The quality of the textbook was conducted three times and the result of each test then was revised in accordance with the findings of the textbook shortage when tested on a limited scale.

Graphically, change in result of critical thinking ability when tested using textbooks in the first, second, and third test can be described as follows:

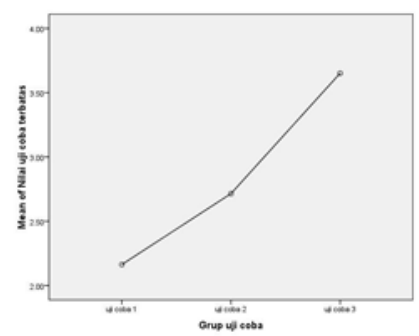

Graphic 1: Change in trend of critical thinking ability value when tested using textbooks in the first, second, and third test

The graphic 5.1 presented that trend of critical thinking ability value from first, second, and third tests got the positive increase

Graphically, the change in the value of creative thinking ability when tested using textbooks in the first, second, and third test trials can be described as follows:

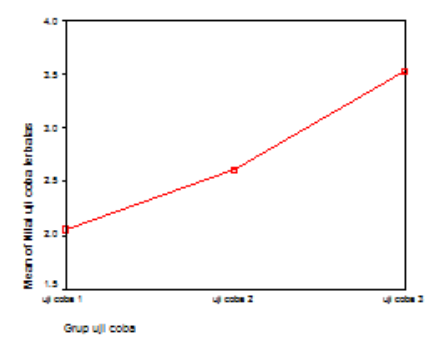

Graphic 2: Change in trend of creative thinking ability value when tested using textbooks in the first, second, and third test

The graphic 5 presented that trend of creative thinking ability value from first, second, and third tests got the positive increase. 
Based on the results of observation on the use of contextual learning based textbooks at 10 IPS 1 and 10 IPS 2 showed that Islamic education teachers conducted the learning activities correctly and suitable to instructions in the textbook and meet the rules of the contextual learning approach.

To ensure the achievement of teacher learning objectives, the student guiding activities are conducted by the teacher by inviting students to discuss what has been described as step in the textbook. The teachers provided feedback to students to further responded by other students and then responded by the teacher.

Stimulus was given by teachers so that students could be active in the learning process. Teachers paid attention to the students who needed during the learning process so that students did not feel bored. To facilitate students in using textbooks, teachers explained the main objectives of learning, the goals to be achieved and to write specific things on the board for students. This materials contained in textbook was written on the board to allow students to know the essence of the material being studied.

Students' active role was facilitated by the teacher so that students could do the task together, solve problems, find ideas and find meaning from the taught material, and explore the experience associated with the material. By working together, one student can benefit from the talents of other students.

In the context of contextual learning, the teachers brought the real world into the classroom and encouraged students to make connections between their knowledge and daily life so that students could solve problems in his life as a member of society and connecting to the concept in learning. ${ }^{7}$

Through a series of activities in textbooks, teachers gave students the opportunity to use high-level thinking using critical thinking and creative thinking ability. The teacher assessed students using authentic assessment directly related to the subject matter being studied.

${ }^{7}$ Nurhadi. (2003:13). Pembelajaran Kontekstual dan Penerapannya dalam KBK. Malang: Penerbit Universitas Negeri Malang
Contextual learning system is a learning process that aims to help students see meaning in the academic material they learn by connecting academic subjects with the context in their daily life, that is with the context of their personal, social and cultural circumstances. To achieve this goal, the system includes the following eight components: making meaningful connections, doing meaningful work, doing self-regulated learning, collaborating, critical and creative thinking, helping individuals to grow and develop, attaining high standards, and using an authentic judgment. ${ }^{8}$

Through the process of developing textbooks, learning problems is also solved based on the development of the ADDIE model. The developed textbook has also been adapted to the contextual learning approach to ensure the learning objectives. Thus, the stages of material and practical activities on the textbook in accordance with contextual learning approach, but still meet the rules of writing good and correct textbook.

To ensure that the learning objectives, the students were given tasks in the form of exercise questions that stimulates students to think critically and creatively in the end of the class. Textbooks were developed with some practice exercise that guides students to improve critical thinking ability and creative thinking ability. The activities were ; observing illustrations of images, writing opinions, reading material, group assignments, connecting and comparing, telling experiences, taking wisdom, planning individual activities and tasks.

The exercises designed in textbooks also make it easier for teachers to conduct a series of summative tests so that the purpose of contextual learning to improve critical and critical thinking ability can be realized and evaluated at each stage of learning designed in textbooks. The textbook can also be defined as a single unit of learning that contains information, discussion and evaluation. Thus, the teacher becomes easy to realize the purpose of textbook such as; the use of developed textbooks and

8 Johnson, Elaine B. (2002:66). Contextual Teaching And Learning. California: Corwin Press Inc. 
contextual learning used in the book can improve students' critical and creative thinking ability.

The evaluation is a formative evaluation done to improve the quality of textbook product. Formative evaluation starts from feasibility testing, expert validation and limited testing to test the reliability of textbook products.

In the development of the ADDIE (Analysis, Design, Development, Implementation and Evaluation) model, the evaluation stage is a formative evaluation. In the design of Dick and Carey model development in step 8 of 10 determined shows that the evaluation in step 8 is formative evaluation distinguished by step 10 that is summative evaluation after going through revision at step 9 at Dick and Carey stage. In Borg and Gall explained that; program developers conduct formative evaluation while the program or product is under development, in order to support the process of improving its effectiveness. ${ }^{9}$

In the evaluation stage, the textbook development through expert validation and test was limited to 33 students for three times to ensure the reliability of textbook. Observation is conducted in learning process to know students' enthusiasm when teachers begin learning and introduce textbooks. Before learning material, students are asked to exploit illustrations of facts through pictures and to provide an opinion. Students are interested to take an active role in learning activities, students are interested to express and write their opinions. Students' interests become more active when the teacher asks students to compare the facts in the form of illustrations of drawings in textbooks with life in the student environment.

This indicates that the developed textbooks is in good criteria of textbooks as Greene and Petty that mention the criteria of a good textbook such textbook should be interesting,

${ }^{9}$ Borg, W.R \& Gall, M.D. Gall. (1989:590). Educational Research: And Introduction, Fith Edition. New York: Longman motivating, loading illustrations and mountains with other lessons. ${ }^{10}$

Students play an active role during the learning process. Learning activities require students to play an active role through learning activities designed in textbooks namely activities; observing illustrations of drawings, writing opinions, reading material, group assignments, connecting and comparing, telling experiences, taking lessons, planning individual activities and tasks. The activities designed in a book stimulate students to take an active role in the learning process.

The effectiveness of textbooks was tested to 84 students. First; before treatment, all subjects were given 10 questions, and the value of the result is called pretest. Second; the subjects of the study were treated using textbooks with 10 questions, and the result value was called posttest. To test the effectiveness of textbook in improving students' critical and creative thinking ability is by analyzing the results of pre test and post test using a score of normalized (gain score).

Through gain score, the effectiveness of the developed contextual learning based textbooks to improve students' critical thinking ability was analyzed through pretest and posttest score data. Table 1 shows the distribution of gain criteria categories of critical thinking skills.

Table 1 Distribution of the gain in critical thinking ability

\begin{tabular}{|l|l|l|}
\hline Category & Subjects & Percentage \\
\hline High & 58 & $69 \%$ \\
\hline Medium & 22 & $26 \%$ \\
\hline Low & 4 & $5 \%$ \\
\hline $\begin{array}{l}\text { Number of } \\
\text { subjets }\end{array}$ & 84 & $100 \%$ \\
\hline Gain score & \multicolumn{2}{|c|}{0.769} \\
\hline
\end{tabular}

In Table 1, the subjects are 84 students, $69 \%$ or as many as 58 students who get the increased gain score in critical thinking ability,

${ }^{10}$ Greene and Petty. (1981:545). Developing Language Skills In The Elementary Schools. Boston: Allyn and Bacon 
or it is categorized as high category, $26 \%$ or as many as 22 students get increased gain score in critical thinking ability, or it is categorized medium category and the remaining $5 \%$ as many as 4 students get increased gain score in critical thinking ability or it is categorized as low category.

With an average gain score of 0.769 or ( $\mathrm{g}>0.7$ ), it can be interpreted that the improvement of students' critical thinking ability after using textbooks is generally in the high category. This suggests that the use of the developed contextual learning based textbooks is effective in enhancing students' critical thinking ability.

The effectiveness of the developed contextual learning based textbooks improve students' creative thinking ability.

Through gain score, the effectiveness of the developed contextual learning based textbooks to improve students' creative thinking ability is analyzed through pretest and posttest score data. Table 2 shows the distribution of gain score of creative thinking ability.

Table 2 Distribution of gain score category of creative thinking ability

\begin{tabular}{|l|l|l|}
\hline Category & Subjects & Percentage \\
\hline High & 69 & $82 \%$ \\
\hline Medium & 15 & $18 \%$ \\
\hline 0 & 4 & $0 \%$ \\
\hline $\begin{array}{l}\text { Number of } \\
\text { subjets }\end{array}$ & 84 & $100 \%$ \\
\hline Gain score & \multicolumn{2}{|c|}{0.775} \\
\hline
\end{tabular}

In table 2, subjects are 84 students, $82 \%$ or as many as 69 students get the incresed gain score of creative thinking ability with high category, $18 \%$ or as many as 15 students get increased gain score of creative thinking ability with medium category.

With an average gain score of 0.775 or $(\mathrm{g}>$ 0.7 ), it can be interpreted that the improvement of students' creative thinking ability after using developed contextual learning based textbook is generally in the high category. This suggests that the use of developed contextual learning based textbook is effective in improving students' creative thinking ability.

\section{Conclusion}

Based on the discussion in this study, it can be concluded that: 1 . Test and textbook validity conducted by four experts includes : validity test of the textbook content, test and systematic testimonies of the textbooks, validity test of the textbook language, and test validity and table, drawing, graphics, and visual textbooks. From 36 items of assessment aspect that were given by the expert, 22 items are considered proper and 14 items are considered feasible, 2. Textbook practicability is intended to ensure the implementation of every aspect of the use of developed contextual learning based textbooks, 3 . Through gain score analysis, it can be seen that improvement of students' critical thinking ability in general is categorized high. Thus, it can be concluded that developed contextual learning based textbooks is effective for improving students ' critical thinking ability of Islamic Education subject in MAN Surabaya, 4. Through gain score analysis, it can be seen that the improvement of students' critical thinking ability in general is categorized high. Thus, it can be concluded that developed contextual learning based textbooks are effective to improve students' creative thinking of Islamic Education subject in MAN Surabaya

\section{Suggestion}

Based on the results of research and explanation, the suggestion can be given as follows: 1. Innovation on development is needed to improve the students' ability and potential especially critical and creative thinking ability so that developed contextual learning based textbook is required to connect between concepts with real life, 2. suggestion for principals at MAN Surabaya, the results of this study can be reference in guiding teachers, 3 . In guiding teachers, principals in MAN Surabaya can also use the results of this research as a formulation to develop textbooks on other subjects so that the development of this textbook is not only limited to the subjects of Islamic Education, 4. For further researchers who are interested to conduct development research or 
interested in the same case, may conduct research in different locations. Thus, this research can be used as a comparison to enrich the repertoire of research, 5. It is expected there is further research on other subjects so that the development of textbooks in this study can be used as a reference to develop textbooks applied to other subjects, 6 . The further issemination is needed so that the development of textbooks can grow more broadly not only in MAN Surabaya but in other schools. The development of textbooks is not limited to the subjects of Islamic Education, but can be developed in other subjects. Thus the function of the use of textbook development research can have a wider impact, 7. Suggestions for the Government and related parties, that looking at the condition in schools / Islamic private school (madrasah) regarding on teacher's ability in developing textbook is still very low. Thus, it needs an effort to continue to improve teacher guidance, especially in developing textbooks on the subjects. In terms of utilization, this research can be used as a reference for teacher in developing textbooks, 8 . To other researchers, it is suggested to assess the reliability and benefit of textbooks on a wider scale through in-depth experimental design.

\section{References}

(1991). Kamus Besar Bahasa Indonesia Edisi Kedua. Jakarta: Balai Pustaka;

Achmadi SS. (2008). Tatasaji Buku Ajar. Pelatihan Penulisan Buku Ajar. Jakarta

Aisyah, T.S. (2008). Penerapan Strategi Konflik Kognitif dalam Pembelajaran Matematika untuk Meningkatkan Kemampuan Berpikir Kritis Siswa. Skripsi Jurusan Pendidikan Matematika FKIP UNPAS: tidak diterbitkan

Ardhana, I. W. (2002). Konsep Penelitian Pengembangan dalam Bidang Pendidikan dan Pembelajaran. Makalah disampaikan pada Lokakarya Nasional Angkatan II
Metodologi Penelitian Pengembangan Bidang Pendidikan dan Pembelajaran, Malang, 22-24 Maret.

Arifin, Zainal. (2011). Evaluasi Pembelajaran. Bandung: Remaja Rosdakarya.

Arikunto, Suharsimi. (2006). Prosedur Penelitian Suatu Pendekatan Praktik. Jakarta: Rineka Cipta.

Association For Educational Communications and Technology. (1977). The Definition Of Educational Technology. Washington D.C: AECT

Agustine, T. (2009). Pengaruh Penggunaan Strategi Heuristik Terhadap Peningkatan Kemampuan Berpikir Kritis Matematika Siswa.

Borg, W.R \& Gall, M.D. Gall. (1989). Educational Research: And Introduction, Fith Edition. New York: Longman

Branch, Robert Maribe. (2010). Instructional Design-The ADDIE Approach. US: Springer

Beyer, Barry K. (1985). Critical Thinking. Blomington: Phi Dhellta Kappa, 408 N Union, PO BOX 789.

Carol, Robert T. (2004). Criticall Thinking: Becoming a Criticall Thinker. UK: Cambridge University Press.

Coleman, J.C dan Hammen, C.L. (1974). Contemporay Psychology and Effective Behavior. Glenview: Scot, Foresmen, and Co

Costa, A.L. (2001). Developing Mind A Resource Book for Teaching Thinking. Virgina USA: ASCD

Degeng, I, N, S. (2001). Pengembangan Model Bahan Ajar Bahasa Indonesia Inklusi. Malang: LP3 Universitas Negeri Malang.

Dirjen Dikdasmen. (2006). Panduan Pengembangan Bahan Ajar. Dirjen Dikdasmen

Dirjen Dikdasmen. (2008). Panduan Pengembangan Bahan Ajar. Dirjen Dikdasmen 
Dirjen Dikdasmaen. (2003). Kerangka dasar Pengembangan Silabus dan sistem Penilaian Hasil belajar Siswa SLTP Berbasis kompetensi. Dirjen Dikdasmen.

Dick, W. \& Carey L. (1985). The systematic desgin of instruction. Illinois: Scott \& Co. Publication.

Drajat, Zakiah, (1992). Ilmu Pendidikan Islam, Jakarta : Bumi Aksara

Eggen, P.D \& Kauchak, D.P. (2012). Educational Psychology: Windows on Classrooms. Upper Sandle River N.J: Pearson/Merrill/Pentice Hall

Efendiy, Khoirul. (2012). Pengembangan Bahan Ajar Pendidikan Agama Islam SMP Kelas VIII dengan Model Dick, Carey \& Carey di SMPN 04 Ampelgading Malang. (Tesis tidak dipublikasikan). Universitas Negeri Malang.

Emzir. (2008). Metode Penelitian Pendidikan: Kuantitatif dan Kualitatif. Jakarta: PT Rajagrafindo Persada.

Facione NC, Facione PA. (1996). Externalizing The Criticall Thinking in Knowledge Development and Clinical Judgement. USA: California Academic Press

Facone NC. (2004). Criticall Thinking What It is and Why It Counts. USA: California Academic Press

Fatirul, A, N. (2008). Paradigma Baru Dalam Pembelajaran. Jurnal Wahana, Volume 51, Nomor 2

Fauzi, A. (2004). Psikologi Umum. Bandung: CV Pustaka Setia.

Farikhatin, Anis. Menyoal Peran Afektif Pendidikan Agama di Sekolah. Makalah ini dipresentasikan dalam Seminar dan Lokakarya Tahap Kedua "Pendidikan Pluralisme dan Multikulturalisme", di Merauke 9 s.d 12 Mei 2011.

Fisher, Alec. (2002). Berpikir Kritis; Sebuah Pengantar. Jakarta: Erlangga

Gay, L.R, Mills, Geofrey E, and Airasian Peter. (2009). Educational Research: Competencies
For Analysis and Aplications. London:Pearson Prentice Hall

Guilford, J.P. (1977). Way Beyond The IQ. Bufalo: Creative Learning Press.

Glasser, E. (1941). An Experiment in the Development of Criticall Thinking. Advanced School of Education at Teacher College, Columbia University.

Greene and Petty. (1981). Developing Language Skills In The Elementary Schools. Boston: Allyn and Bacon

Hake, R. Richard. 1998. Interactive Engagement versus Traditional Method: A Six-Thousand-Student Survey Mechanics Test Data for Introductory Physics Courses. American Journal of Physics

Hasan, Mohamad Tholhah. (2005). Islam dan Masalah Sumber Daya Manusia. Jakarta: Lantabora Press

Harris, R. (1998). Introduction To Creative Thinking.(Online)

Http://www.virtualsalt.com/crebook1.htm.

Hartono. (2012). Pengembangan Bahan Ajar Pendidikan Agama Islam Berbasis Pembelajaran Tematik Pada Siswa Kelas III Madrasah Ibtidaiyah. (Tesis tidak dipublikasikan). UIN Maulana Malik Ibrahim.

Huda, Nuril. (1999) Language Learning and Teaching. Malang: Ikip Malang Publisher.

Izzati, N. (2009), Berpikir Kreatif dan Kemampuan Pemecahan Masalah Matematis: Apa, Mengapa, dan Bagaimana Mengembangkannya Pada Peserta Didik. Prosiding Seminar Nasional Matematika dan Pendidikan Matematika, Bandung 19 Desember 2009,

Jannah, Raudlatul. (2009). Pengembangan Paket Pembelajaran Pendidikan Agama Islam Kelas VIII dengan Model Dick, Carey dan Carey di SMP Negeri 2 Banyuwangi. (Tesis tidak dipublikasikan). Universitas Negeri Malang

Januszewski, A \& Molenda, M. (2008). Educational Technology: A Definition With 
Commentary. New York: Lawrence Erlbaum Associates

Johnson, Elaine B. (2002). Contextual Teaching And Learning. California: Corwin Press Inc.

Johnson, Elaine B. (2000). Contextual Teaching And Learning. California: Corwin Press Inc.

Kasihani, K.E. Suyanto. (2007). English for Young learners. Jakarta: Bumi Aksara.

Komalasari. (2010). Pembelajaran Kontekstual: Konsep dan Aplikasi. Bandung: Refika Aditama.

Krulik, S and Rudnick, J. A. (1995). The New Sourcebook For Teaching Reasoning and Problem Solving in Elementary School. Massachusetts: Allyn \& Bacon.

Landrawan. (2008). Pengembangan Pembelajaran Kontekstual Berbasis Masalah Untuk Meningkatkan Hasil Belajar IPS Siswa Kelas II SMPN 1 Tejakula-Singaraja. Jurnal Pendidikan dan Pengajaran. Volume 1 , Nomor 2

LTSIN. (2001). Learning Teaching. Scotland: Learning and Teaching Scotland

Meusburger, Peter. (2009). Milious Of Creativity: The Role Of Places, Environments and Spatials Context. Springer

Mintowati. (2003). Panduan Penulisan Buku Ajar. Jakarta: Depdiknas

Misdan, U. (1986). Telaah Buku Teks dan Kurikulum (Modul UT). Jakarta: Karunika

Muhaimin. (2009). Rekonstruksi Pendidikan Islam. Jakarta: Raja Grafindo Persada.

Muhaimin. (2004). Wacana Pengembangan Pendidikan Islam. Surabaya: Pusat Studi Agama Politik dan Masyarakat.

Muhaimin. (2005). Pengembangan Pendidikan Islam. Surabaya: Pusat Studi Agama Politik dan Masyarakat.

Mukhtar. (2003). Desain Pembelajaran Pendidikan Agama Islam. Jakarta: CV Misaka Galiza

Munandar, U. (2009). Pengembangan Kreativitas Anak Berbakat. Jakarta: Rineka Cipta.
Mc. Kinnon, D.W. (1962). The Nature and Nurture of Creative Talent.Americant Psychologist. 17.(7).

Nurhadi. (2003). Pembelajaran Kontekstual dan Penerapannya dalam KBK. Malang: Penerbit Universitas Negeri Malang

Nurhadi dkk. (2004). Pembelajaran Kontekstual dan Penerapannya dalam KBK. Malang: Penerbit Universitas Negeri Malang.

Nurlaela, Luthfiyah dan Ismayati, Euis. (2015). Strategi Belajar Berpikir Kreatif. Yogyakarta: Penerbit Ombak.

Pannen dan Purwanto. (1997). Penulisan Bahan Ajar. Jakarta: Dirjen DIKTI

Pannen dan Purwanto. (2001). Penulisan Bahan Ajar. Jakarta: Dirjen DIKTI

Permendiknas No 16 Tahun 2007 Tentang Standar Kualifikasi Akademik dan Kompetensi Guru.

Purwanto, M.N. (2010). Prinsip-Prinsip dan Teknik Evaluasi Pengajaran. Bandung: Remaja Rosdakarya.

Rachmawati, W, S. (2004). Anatomi Buku Ajar. Jakarta: Departemen Pendidikan Nasional.

Radiansyah, I. (2010). Mengembangkan Kemampuan Berpikir Kritis. http://lkpk.org/2010/12/01

Kemampuan_Berpikir_Kritis. Diakses 29 Januari 2015.

Richadeau, F. (1980). The Design and Production Of Textbook: A Practical Guide Gower.

Richey, Rita and Klein, C. (2007). Design And Develompment Research. London: Lawrence Erlbaum Associates. Inc.

Rofi'uddin, A. (2000). Model Pendidikan Berpikir Kritis. Tim Pengembang Jurnal Universitas Negeri Malang

Sanjaya, Wina. (2011). Strategi Pembelajaran Berorientasi Standar Proses Pendidikan. Jakarta: Kencana Prenada Media. 
Samani, Muchlas. (2012). Profesionalisasi Pendidikan. Surabaya: Unesa University Press.

Samani, Muchlas., Nurlaela, Lutfiyah., Widodo, Wahono., Inzanah. (2016). Berpikir Tingkat Tinggi Problem Solving. Surabaya: Sarbikita Publishing

Sarapung, Elga dan Widianto, Tri. (2005). Pluralisme, Konflik \& Pendidikan Agama di Indonesia. Yogyakarta: Dian Interfidei

Schafersman, Steven D. (1991). An Introduction to Criticall Thinking. USA: California Academic Pres

Seels, B. B \& Richey, R. C. (1994). Instructional Technology: The Definition and Domains Of The Fields. Washington D.C: AECT

Siswono, T.Y.E. (2009), Meningkatkan Kemampuan Berpikir Kreatif Siswa Melalui Pemecahan Masalah Tipe "What's Another Way".Jurnal

(Online)http://tatagyes.files.wordpress.com/2 009/11/paper07_jurnalpgriyogja.pdf,

Desember 2012)

Sitompul, R. (2003). Memacu Kompetensi Kreatif Melalui Pembelajaran. Pelangi Pendidikan, 10 (3).

Sudiarta, I, G P. (2007). Pengembangan Pembelajaran Pendekatan Tematik Berorientasi Pemecahan Masalah Matematika Terbuka Untuk Mengembangkan Kompetensi Berpikir Divergen, Kritis dan Kretaif. Jurnal Pendidikan dan Kebudayaan. No. 069 Tahun 13: 1004-1024

Sugiarto. (2011). Landasan Pengembangan Bahan Ajar. Materi Workshop Penyusunan Buku Ajar Bagi Dosen Politeknik Kesehatan Kemenkes Semarang. 2 Maret.

Sugiyono. (2006). Metode Penelitian Kuantitatif Kualitatif dan R\&D. Bandung: Alfabeta.

Sugiyono. (2011). Metode Penelitian Kuantitatif Kualitatif dan R\&D. Bandung: Alfabeta.
Sumarni. (2012). Model-Model Pembelajaran. Malang: Aditya Media Publishing

Sun, P.K. (2011). Menikmati Belajar Secara Kreatif. Yogyakarta: Samudra Biru.

Suparman, M. Atwi. (2012). Desain Intruksional Modern. Jakarta: Erlangga.

Tafsir, Ahmad. (2005). Ilmu Pendidikan Dalam Persfektif Islam, Bandung : PT. Remaja Rosdakarya

Tarigan, Henry Guntur dan Djago Tarigan. (1986). Telaah Buku Teks Bahasa Indonesia. Bandung: Angkasa

Tarigan, D \& Tarigan. (1986). Teknik Pengajaran Keterampilan Berbahasa. Bandung: Aksara

Trianto. (2009). Mendesain Model Pembelajaran Inovatif Progresif: Konsep, Lanadasan dan Implementasi Pada Kurikulum Tingkat Satuan Pendidikan. Jakarta: Kencana Prenada Media Group.

Trianto. (2009). Mendesain Model Pembelajaran Inovatif Progresif: Konsep, Lanadasan dan Implementasi Pada Kurikulum Tingkat Satuan Pendidikan. Jakarta: Kencana Prenada Media Group.

Trianto. (2007). Model Pembelajaran Terpadu dalam Teori dan Praktek. Jakarta: Prestasi Pustaka.

Undang undang Nomor 20 Tahun 2003 Tentang Sistem Pendidikan Nasional

Wardhani, P.P. (2011), Kemampuan Berpikir Kritis Dan Kreatif Matematika. http://furahasekai.wordpress.com/2011/10/0 6/kemampuan-berpikir-kritis-dan-kreatifmatematika/, (29 Nopember 2012).

Walker, Paul \& Finey, Nicholas (2006). Skill Development and Critical Thinking In Higher Education. London: University College, Higger Education Research \& Development Unit

Williawati, L. (2009). Pengaruh Pembelajaran Matematika dengan Pendekatan Diskursus terhadap Kemampuan Berpikir Kritis Siswa dalam Matematika. Skripsi Jurusan 
Pendidikan Matematika FKIP UNPAS: tidak diterbitkan

Zuhaerini, (1983). Metodik Khusus Pendidikan Agama. Surabaya : Usaha Nasional. 